$21-2-7$

7 月 21 日

$10: 45$

第 2 会場
遊離肝細胞を用いた有機アニオン系蛍光色素、ANS の 䀒輸送機構の解明 : 種々のアニオン系色素の影響

【目的】前回の薬物動態学会において、Scharschmidt らのいう invivoでの "対向輸送（counter-transport）" 現象が 1-anilino-8-naphthalene sulfonate (ANS) においてもみられることを報告した。即ち、ANS を iv 投与 10 分 後、他の有機アニオン類を投与すると、ANS 血中濃度が一過的に上昇し、真の 対向輸送の機構のみならず、細胞内結合の置換機構も関与していることを示し た。1) 有機アニオン類には rose bengal（RB）のように投与後 ANS の血中消 失の促進を引き起こし、引䌇き再上昇を生じさすタイプと bromophenolblue （BPB）のように投与後すぐに血中浱度再上昇を引き起こすタイプが見られた (Fig.1)。そこで本研究では、ラット遊離肝細胞を用いて ANS 肝輸送に関する より詳細な kinetic parameter を求めることにより、他の有機アニオンによる 見かけの対向輸送タイプの違いが生じる機構について検討した。

【実験方法】Wistar系雄性ラット(200-250g）からコラゲナーゼ潅流法により 遊離肝細胞を調整した。ANS の肝細胞への取り込みは centrifugal filtration 法により侎々な浱度の有機アニオン存在下での ANS 取り込み初速度（60 sec まで）を求めた。さらに、ANS の血槳中タンパク結合に対する種々の有機 アニオンの影響を平衡透析法を用いて調べた。ANS は、蛍光（Ex：400，Em： $480 \mathrm{~nm}$ )により定量した。

【結果と考察】Fig.2 に示すDixon plot により種々の有機アニオンは競合的 にANS の肝取り込みを阻害することが分かる。取り込みに対する阻害定数 (Ki) は、RB が最も小さく $(\mathrm{Ki}=7 \mu \mathrm{M})$ 、次いで bromosulfoph thalein (BSP), BPB が約 $20 \mu \mathrm{M}$ であった。Fig.3にANS の血墏中タンパク結合に対する種々 の有機アニオンの影響を示した。RB，BSP，BPB は、ANSの血墏中非結合型分率 $\left(f_{\text {ANS }}\right)$ を顕著に増加させた。一方、有機アニオン類を $60 \mu \mathrm{mol} / \mathrm{Kg}$ iv 投与後

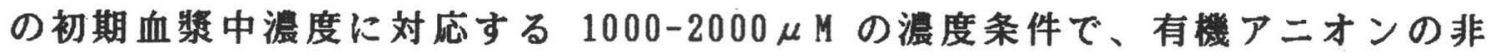


結合型浱度は、RBで、1-2 4 M であり取り込みに関する Ki 值よりも低い值を 示した。一方、BPB，BSP では、それぞれ 30-60 も充分に大きな值を示した。以上の in vitro 実験結果より、RB 投与時には、

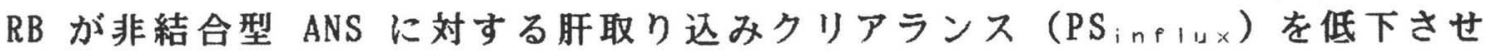
ることなく、 $\mathrm{f}_{A N S}$ のみ增加させたことにより、ANS 取り込みの増加を引き起こ したものと考察できる。これに対して、BSP,BPB 投与の場合は、これら有機ア ニオンによる $\mathrm{f}_{\mathrm{ANS}}$ の増加と $\mathrm{PS}_{\mathrm{i} n \mathrm{f} \mathrm{Iux}}$ 低下の両方が生じ、 net の効果として は、取り込み阻害が生じたものと思われる。更に、ANSの efflux に関するパ ラメーターを求め、in vivo 実験と統合することにより、drug-drug interaction の機構について定量的考察を加えた。

\section{【参考文献】1）薬物動態 3（5）38-39（1988）}
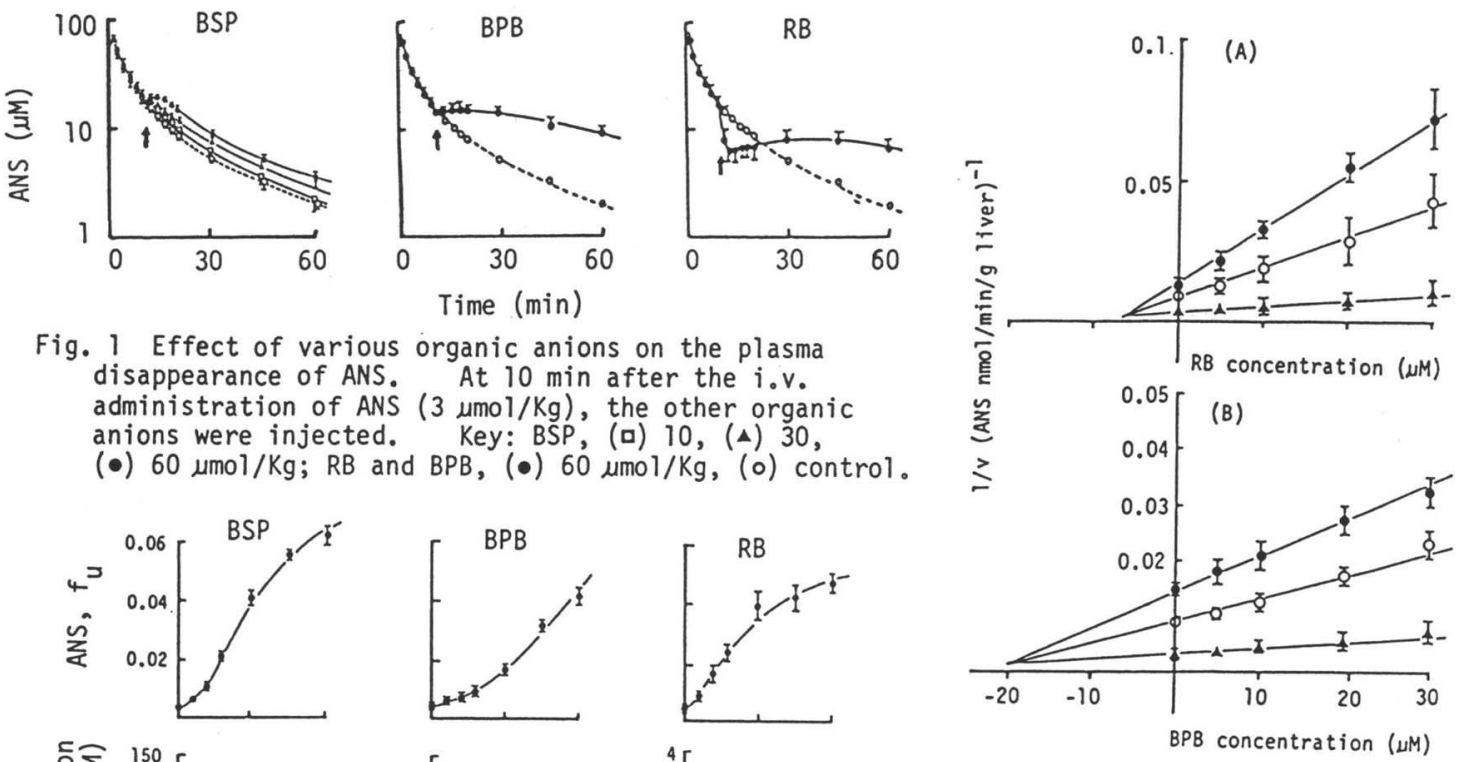

Fig. I Effect of various organic anions on the plasma disappearance of ANS. At $10 \mathrm{~min}$ after the $i . v$. administration of ANS $(3 \mu \mathrm{mol} / \mathrm{Kg})$, the other organic anions were injected. Key: BSP, (ם) 10, (4) 30 ,

(•) $60 \mu \mathrm{mol} / \mathrm{Kg} ; \mathrm{RB}$ and $\mathrm{BPB},(\bullet) 60 \mu \mathrm{mol} / \mathrm{Kg},(0)$ control.
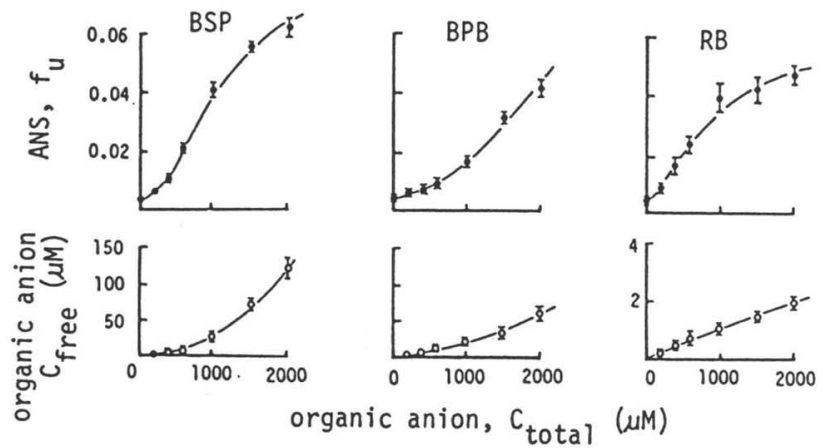

Fig. 2 Dixon plots of ANS uptake in the presence of $R B(A)$ or $B P B(B)$. Key: concentration of ANS, (๑) $5 \mu \mathrm{M}$; (o) $10 \mu \mathrm{M}$; (4) $40 \mu \mathrm{M}$.

Fig. 3 Inhibitory effect of various organic anions on the ANS binding to plasma protein. Initial ANS concentration, $400 \mu \mathrm{M}$. 